International Journal of Agriculture, Environment and Bioresearch

Vol. 4, No. 04; 2019

ISSN: $2456-8643$

\title{
FACTORS AFFECTING ADOPTION OF IMPROVED OIL PALM PRODUCTION TECHNOLOGIES BY WOMEN IN IFE-SOUTH LOCAL GOVERNMENT AREA OF OSUN STATE, NIGERIA
}

\author{
${ }^{1}$ OLAPADE-OGUNWOLE, Folayimi*, ${ }^{2}$ TAIWO, John Olayinka and ${ }^{3}$ OJEDOKUN, Idris Kayode \\ ${ }^{1}$ Department of Agricultural Economics, Ladoke Akintola University of Technology, Ogbomoso, Oyo, Nigeria. \\ ${ }^{2}$ Ladoke Akintola University of Technology, Ogbomoso, Oyo, Nigeria. \\ ${ }^{3}$ Department of Agricultural Economics, Ladoke Akintola University of Technology, Ogbomoso, Oyo, Nigeria.
}

http://doi.org/10.35410/IJAEB.2019.4410

\begin{abstract}
Palm oil is the main edible vegetable oil produced and consumed in Nigeria and is an important ingredient in most Nigerian households, important for nutritional and medicinal purposes. The work studied the factors affecting adoption of improved oil palm production technologies by women in Ife-South local government area of Osun state, specifically look at the socio-economic characteristics of women oil palm processors, the level of awareness of improved oil palm processing technologies among women processors, sources of information on improved oil palm processing technologies, the reasons for non adoption of the improved oil palm processing technologies by women processors and effects of adopting improved oil palm processing. Technologies on rural women's oil yield, income and level of living.
\end{abstract}

A multistage sampling technique was adopted to select 125 respondents who were interviewed with the aid of structured questionnaire. The data were analyzed using both descriptive and inferential statistics (Pearson product moment correlation statistic).

The result showed that $61.1 \%$, of the respondents were between the age ranges of greater than 50 years with the mean age of 54 years, $55.6 \%$ of the respondents had household size between 6-10 household members, $60.0 \%$ of the respondents spent between 1-6 years in school, $64.4 \%$ of the respondents had between 20-40 years in Oil palm production, $84.4 \%$ of the respondents did not have any visit by extension agent, $41.1 \%$ of the respondents had access to credit, $75.6 \%$ of the respondent sourced their credit through Esusu, $\mathrm{F}$ cal which is 1.812 is slightly higher than the $\mathrm{F}$ table value which is 1.590 but not significant at any level and it may be due to the low level of adoption, household size was significant at $1 \%$ level but negatively correlated, years of processing experience was significant at $1 \%$ and $5 \%$ level and positively correlated, credit and extension agents' visitation were significant at 5\% level and were positively correlated, complexity was significant at $5 \%$ level but negatively correlated, sources of information was significant at $1 \%$ level.

In conclusion, sources of information and complexity had effects on adoption of the modern processing technologies and use of improved technologies should be practiced by all oil palm producers. 
Keywords: Adoption, Oil palm production, improved technology.

\section{INTRODUCTION}

Nigeria ranked sixth among the poorest countries in the world with over $70 \%$ of the population living below poverty line in 2007 (Central Intelligence Agency, 2012). Palm oil is the main edible vegetable oil produced and consumed in Nigeria where the oil palm tree features regularly in the natural vegetation of the lowland humid to sub-humid areas in a belt that covers almost 24 million hectares (ha) (Opeke, 2013). Dispersed smallholders harvest fruits from the wild/semiwild palms and process them to produce $80 \%$ of the palm oil output and through which Nigeria accounted for $43 \%$ of global palm oil production up till the mid-1960s. The performance has declined such that the annual output at 850,000 metric tonnes (MT) leaves an overall supply gap of 0.5 million MT currently met through imports (Omoti, 2011). Palm oil production starts with the oil palm trees whose cultivation has formed the farming culture and a means of livelihood for millions of families in the rural landscape. Palm oil production is a major vocation which has played significant roles in poverty alleviation in some countries, especially in Malaysia, Nigeria and Indonesia (Business Day, 2013).

Oil Palm tree is one of the most important tree crops in Nigeria which has contributed greatly to the economic development of the country. According to Nwajiuba and Akinsanmi 2013), Oil palm (Elaeis guineensis) is the most important tree crop in the rural economy of the humid rainforest of Eastern Nigeria. The oil is consumed as household food, used for industrial purposes and is an important export commodity for foreign exchange earnings for Nigeria. Its [production and processing serve as an employer of labour for many of the rural populace in the producing areas, Onwubuya (2007) noted that Nigeria until 1966 was the largest producer and exporter of palm oil and kernel accounting for 30 per cent of world's palm oil and 50 percent of world's palm kernel. However, its contributions as an export and foreign exchange earner started declining since the 1970's as Nigeria's petroleum earnings escalated, drawing labour away from the rural farm sector to the urban non-farm sectors.

In Nigeria, most of the oil palm is produced by traditional methods and women play active role in the production and marketing of oil palm. These traditional methods are labour-intensive and inefficient (Ituen and Modo, 2010). In the same vein, Opeolu and Oluwalana, (2013) found that traditional processing technologies are labour intensive and have relatively low extraction efficiency of only 55 percent. Women are the major stakeholders in agricultural production in Africa and especially in Nigeria (Opeolu and Oluwalana, 2013). According to Spore (1993), women in Africa make up more than 33 per cent of the work force. They account for 70 percent of agricultural labour, 80 percent of food producers, 100 percent of those who process basic foodstuffs and they undertake 60-90 per cent of the marketing. Omoti (2013) observed that production both in terms of fresh fruit bunches and oil palm is not readily estimated before disposal in sales and consumption. Precluding the weaknesses in the statistics of the industry, current estimates of oil palm production in the country are about 900,000 metric tonnes of palm oil and 500,000 metric tonnes of palm kernel annually. Omereji (2015) reported that the domestic and industrial needs of oil palm are well above one million metric tonnes per annum. A shortfall in domestic production of the nation's domestic demand of oil palm is estimated at over 200,000 tonnes of the commodity per annum. 
The increase in demand for palm oil necessitated the improvement of the crop, the method of cultivation and ways of tapping its vast potentials. In order to accomplish this, the Nigerian Institute for Oil Palm Research (NIFOR), formerly West African Institute for Oil Palm Research (WAIFOR) was established near Benin City, Edo State, (NIFOR, 1981). This Institute embarks on various trials in developing, breeding and adapting the crop to Nigeria's environment, towards resuscitating her Agro Based enterprises. They have produced many improved seedlings of this tree crop. They also made some efforts to improve on traditional milling processes by producing simple and affordable small-scale mills. The method of oil palm processing adopted by most processors involves the use of manual labour which results in low output and high level of wastage during processing. This was in line with the National Institute for Oil Palm Research (NIFOR, 1987) estimation, that palm oil loss due to inefficient processing are 250,000 tonnes per annum. It was of the view that Nigeria oil palm industry is on the decline because of the traditional method of processing which is labour intensive and inefficient. NIFOR claimed that suitable and efficient technologies do not exist in rural areas where the main bulk of the fruits are processed and as a result, about 60 per cent of the fresh fruits are not harvested from oil palm trees. Modernizing small-scale palm oil industry will eventually fill the gap of increased domestic demand and will enable Nigeria re-enter the export trade. There has therefore, been the expressed concern to modernize the agricultural sector by using improved technologies to boost production. One of the strategies is the use of improved technologies with the view that they will improve the productivity of farmers. However, the effect can be better understood when the awareness and adoption of improved oil palm processing technologies, the oil yield and level of living of women processors are determined.

The objective of this study is to examine factors adoption of improved oil palm processing technologies by women in Ife South Local Government Area of Osun State. The study is specifically meant to: describe the socio-economic characteristics of women oil palm processors, determine the level of awareness of improved oil palm processing technologies among women processors, identify the sources of information on improved oil palm processing technologies in the study area, find out reasons for non adoption of the improved oil palm processing technologies by women processors and identify the effects of adopting improved oil palm processing Technologies on rural women's oil yield, income and level of living.

\section{METHODOLOGY}

The study was conducted in Ife South local government of Osun, the council is located 45 $\mathrm{km}$ south of the ancient city of Ile-Ife. The council is geographically located between latitude $8^{\circ}$ north of the equator and longitude $4^{\circ} 3^{\prime}$ east of the Greenwich. It falls between the belt which has its rainfall from March to November. Its annual rainfall range between 45-50 inches and last from late March to early November. Its dry season which extends from November to February, has always punctuated with harmattan. The people are predominantly farmers and the concentrate of oil palm farmer especially women in the area along side with other farming activities. A multistage sampling technique was adopted to select 125 respondents. Five out of 10 political wards in the Local Government Area was selected followed by random selection of 5 villages each from each ward. Also, 5 farmers were furthered selected from each village making a total of 110 respondents for the study. Primary data were collected using a well-structured questionnaire. The data collected were analyzed using both descriptive and inferential statistics. The descriptive statistical tools employed include the mean, frequency distribution table and 
percentages to present the socioeconomic characteristics of the respondents while Pearson product moment correlation statistic was used to test for the hypothesis.

\section{RESULT AND DISCUSSION}

\section{Socio economic characteristics}

According to the result in Table $1,100 \%$ of the respondents were female, $61.1 \%, 30.0$ and $8.9 \%$ of the respondents were between the age ranges of greater than 50 years, 41-50 years and less or equal to 40 years respectively, $55.6 \%, 42.2 \%$ and $2.2 \%$ of the respondents had household size between 6-10 household members, 1-5 household members and greater than 10 household members respectively, $60.0 \%, 25.6 \%$ and $14.4 \%$ of the respondents spent between 1-6 years in school, 7-12 years in school and greater than 12 year in school respectively, 64.4\%, $27.8 \%$ and $7.8 \%$ of the respondents had between $20-40$ years in Oil palm production, less or equal to 20 years in Oil palm production and greater than 40 years in Oil palm production respectively, $84.4 \%$ of the respondents did not have any visit by extension agent during the last production season while $14.6 \%$ of the respondents had extension visit, $41.1 \%$ of the respondents had access to credit, $75.6 \%, 60.0 \%, 52.2 \%, 36.7$ and $11.8 \%$ of the respondent sourced their credit through Esusu, friends and family, cooperative, money lender and Banks respectively.

Table 1: Socio-Economic Characteristic of the Respondents

\begin{tabular}{lll}
\hline Socio economic characteristics & Frequency & Percentage \\
\hline Sex & 0 & 0 \\
Male & 90 & 100.0 \\
Female & & \\
Age & 8 & 8.9 \\
$\leq 40$ & 26 & 30.0 \\
$41-50$ & 56 & 61.1 \\
$>50$ & & \\
Household size & 38 & 42.2 \\
$1-5$ & 50 & 55.6 \\
$6-10$ & 2 & 2.2 \\
$>10$ & & \\
Years Spent in School & 54 & 60.0 \\
$1-6$ & 23 & 25.6 \\
$7-12$ & 12 & 14.4 \\
$>12$ & & \\
Years of Processing Oil Palm & 25 & 27.8 \\
$\leq 20$ & 58 & 64.4 \\
$20-40$ & 7 & 7.8 \\
$>40$ & & \\
Extension Visit & 14 & 14.6 \\
Yes & 76 & 84.4 \\
Never & &
\end{tabular}




\section{Access to Credit}

Yes 37

41.1

No

Sources of Credit****

Cooperative

Friends and family

Money Lenders

Esusu

Bank

Source: Field survey, 2018.

11.8

\section{Level of Awareness and Adoption}

According to Table 2, 37.8\%, 21.1\%, 18.9\%, $15.6 \%$ of the respondents had knowledge of existence of threshing machine, digester, sterilizing machine and separating machine respectively while the remaining $3.3 \%$ are aware of the presence of manual/motorized press and oil clarifier respectively, $66.7 \%$ of the respondents have been using improved technologies, $35.6 \%$ of the respondents used sterilizing machine, $24.4 \%$ did not use any of the technology, $21.1 \%$ used threshing machine while $18 \%$ of the respondents used separating machine, $91.1 \%, 60.0 \%$, $52.2 \%, 33.3 \%$ and $17.3 \%$ of the respondents reported that lack of capital, few availability of improved technologies, high cost of improved technologies, distance to processing area and change in taste, colour and stickiness by the improved technologies deter them from using it.

Table 2: Level of Awareness and Adoption by the Respondents

\begin{tabular}{lll}
\hline Level of awareness and adoption & Frequency & Percentage \\
Type of Improved Technology & 34 & \\
Threshing Machine & 17 & 37.8 \\
Sterilizing Machine & 19 & 18.9 \\
Digester & 14 & 21.1 \\
Separating Machine & 3 & 15.6 \\
Manual/Motorized Press & 3 & 3.3 \\
Oil clarifier & & 3.3 \\
Use of Improved Technology & 60 & \\
Yes & 30 & 66.7 \\
No & & 33.3 \\
Types of Improved Technology Adopted & 22 & \\
Non & 19 & 24.4 \\
Threshing machine & 32 & 35.1 \\
Sterilizing machine & 17 & 18.9 \\
Separating machine & & \\
Reasons for Non-Adoption*** & 82 & 91.1 \\
Lack of capital & 47 & 52.2 \\
High cost of improved technology & 54 & 60.0 \\
Few availability &
\end{tabular}


Distance to processing area

Source: Field Survey, 2018.

\section{Relationship between Income before and After Adoption}

Table 3 revealed that $F$ cal which is 1.812 is slightly higher than the $F$ table value which is 1.590 but not significant at any level and it may be due to the low level of adoption.

Table 4 revealed Pearson Product Moment Correlation showed that there were positive relationship between two of the four socio economic variables and adoption of improved palm Oil processing technologies at $1 \%$ and $5 \%$ level of significance. Age and years spent in school were not significant at any level with the level of adoption of modern palm oil processing technologies. It was revealed that household size was significant at $1 \%$ level but negatively correlated, this means that the higher the number of household members the less the level of adoption and this is because they might not actually experience how tedious it is if they were to be very few. Being few will encourage them to adopt more modern technologies in palm oil processing. Years of processing experience was significant at $1 \%$ and $5 \%$ level and positively correlated, this means that the higher the number of years spent in school, the more they will be exposing to the modern technologies and this will give them more insight into best way of carrying out those processing which will gear them into adopting the best and easiest means of processing palm oil (modern technologies). Credit and extension agents' visitation were significant at 5\% level and were positively correlated. This implies that the more the credit facilities available to them and the increase in number of visitation of the extension agents lead to more adoption of modern processing methods. The credit will give them more chance of obtaining the machine involved while the extension agents will create more awareness among the processors and informed them of the advantages of modern technologies over traditional methods of palm oil processing. Complexity was significant at 5\% level but negatively correlated, this means that the processors view modern palm oil technologies as too complex compare to the traditional method which level of adoption will be adversely affected. Sources of information was significant at $1 \%$ level, this indicates that the more the processors exposed to information about use of modern palm oil processing techniques, the increase in the level of adoption.

Table 3: Distribution of the respondents by income before and after the level of adoption

\begin{tabular}{lccccc}
\hline Variable & Mean & SD & F Cal & F table & Sig \\
\hline Income after & 39888.89 & 36035.922 & 1.8121 & 1.590 & 0.182 \\
Income before & 84077.78 & 66531.945 & & & \\
\hline
\end{tabular}

Source: Field Survey, 2018. 
Table 4: Relationship between Selected Socio-economic, Institutional, and Technological Factors and Adoption of Improved Palm oil processing Technologies

\begin{tabular}{|c|c|c|c|c|c|c|c|c|}
\hline Variable & XI & $\mathrm{X} 2$ & $\mathbf{X 3}$ & $\mathrm{X4}$ & $\mathrm{X5}$ & X6 & $\mathbf{X 7}$ & X8 X9 \\
\hline Age & 1 & & & & & & & \\
\hline Years spent in School & -0.062 & 1 & & & & & & \\
\hline Household size & 0.069 & $-0.217 *$ & 1 & & & & & \\
\hline Years of Experience & $0.700 * *$ & $-0^{-278^{* *}}$ & $0.240 *$ & & & & & \\
\hline Credit obtained & 0.064 & $0.461^{* *}$ & -0.050 & -0.038 & & & & \\
\hline Extension Agents Visitation & 0.077 & -0.021 & $0.220 *$ & 0.033 & 0.103 & 1 & & \\
\hline $\begin{array}{l}\text { Compatibility of Modern } \\
\text { technologies }\end{array}$ & -0.143 & -0.077 & 0.160 & -0.011 & 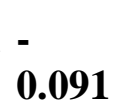 & 0.096 & 1 & \\
\hline $\begin{array}{l}\text { Complexity of Modern } \\
\text { technologies }\end{array}$ & -0.101 & $-0.256^{*}$ & -0.145 & -0.025 & - & $\begin{array}{l}-0.173 \\
1\end{array}$ & 0.203 & \\
\hline Information Sources & 0.084 & $0.249 *$ & -0.096 & -0.188 & 0.115 & $\begin{array}{l}-0.079 \\
0.043\end{array}$ & $-0.243^{*}$ & 1 \\
\hline
\end{tabular}

Sources: Computer Analysis of Correlation, $2018 * * *=$ Significant at $0.01=$ Significant at 0.05

\section{CONCLUSION AND RECOMMENDATION}

Based on the findings of the studies the following recommendations were made;

Women within middle age should be involved in Oil palm processing in order to increase production. The use of improved technologies should be practiced by all oil palm producers in the study area. Government should provide subsidy for the women in order to have a stable market for oil palm. Young active and educated Nigerians should be encourage going into oil palm processing business. The women should be encouraged not to keep the product for too long to avoid spoilage

\section{REFERENCE}

Adamu, C.O., Apata, O.M. and Oyeyinka, R.A. (2012): Processors' awareness and utilization of improved palm oil production technologies in Oyo State, Nigeria. Nigerian Journal of Rural Sociology 13: 1-6.

BusinessDay, (2013): Nigerian Oil Palm Industry (2013): Business Day Online, 14th August 2013. 
Central Intelligence Agency (CIA) (2012): The World Fact Book. https://www.cia.gov/library/publications/the-world-factbook/.

Ituen, E.U.U. and Modo, I.V.O. (2010): The effect of the fermentation period on palm oil Production in Eastern Nigeria using traditional method. http://www.nuffic.nl/ciran/ikdm/8-1. Access date 6/2212016.

Nwajiuba, C. and Akinsanmi, A. (2013): Implication of improved Oil palm (Elaeis guineensis) fruit processing technologies for labour and income among rural household in Imo state, Nigeria. http://www.tropontag.de/2013/abstract/full/138.pdf. access date 09/17/2017

Onwubuya, I.I. (2007): Oil palm (Elaeis guineensis) Development in Nigeria, with particular reference to the Southeast Agro-ecological Zone, http://www.tropontag.de/2013/abstract/full/138.pdf

Opeolu, B.O. and Oluwalana, E.O.A. (2013): Women Empowerment for enhance private sector participation for sustainable Agriculture. Paper presented at the $18^{\text {th }}$ annual conference of Farm Management Association of Nigeria (FAMAAN). Held at University of Calabar, Nov. $24^{\text {th }}-28^{\text {th }}$ Pp. 3-9.

Omereji, G.O. (2015): The oil palm Industry: Vultivation, Processing and Trade. Mindex

Publisher, Benin City, Nigeria, Pp. 33. Onona, B.T., Oni, A.O. and Nwagge, A.O. (2005). Adoption of improved cassava variety and its welfare impact on farming household in edo state, Nigeria. Journal of Agriculture and Food information 7(1): 41-54.

Omoti, U. (2013): Oil palm Research at NIFOR, Nigeria. Page 18.

Omoti U. (2011): The future of the oil palm industry in Africa and strategies for development.

The Nigerian situation. Paper prepared for the Africa Development Bank (ADB) workshop on the future of oil palm industry in Africa and strategies for development, Cote D'Voire.

Opeke, L.K. (2003): Tropical Commodity Tree Crops. Spectrum Books Limited, Ibadan. 503 pp. 